\title{
Ecological and economic evaluation of biogas from intercrops
}

\author{
Nora Niemetz ${ }^{*}$ and Karl-Heinz Kettl
}

\begin{abstract}
Background: Biogas made from main crops (e.g., corn) is commonly used for producing electricity and heat. Nevertheless, the production of energy from monocultures is highly unsustainable and not truly renewable. Since neither monocultures nor food competition are desirable, intercrops can be used to increase the yield per hectare instead of leaving agricultural fields unplanted for soil regeneration. The extra biomass can be used for biogas production. In a case study, the economic as well as the ecological feasibility of biogas production using intercrops, cattle manure, grass and corn silage as feedstocks for fermenters was analyzed.

Methods: The set-up for the case study included different feedstock combinations as well as spatial distributions of substrate supply and heat demand for modeling and optimization. Using the process network synthesis, an optimum structure was generated representing the most economical technology constellation which included transport of substrates, heat and biogas (when applicable). The ecological evaluation was carried out by using the sustainable process index method.

Results: The application of both methodologies to different scenarios allowed a constellation to be found which is economically feasible while entailing low ecological pressure. It is demonstrated that the production of intercrops for producing biogas has so far not been regarded as a viable option by the farmers due to a variety of barriers. Sensitization is needed to emphasize that planting intercrops holds many advantages like positive effects on soil regeneration and raised nitrogen fixation, as well as increased biomass output per hectare and, last but not least, it allows the production of energy without conflicts between food and energy production.
\end{abstract}

Conclusions: Using intercrops for the production of biogas has the potential to decrease the ecological footprint decisively while still offering opportunities in the lucrative biogas market. The transfer of know how regarding this option should be taken up by agricultural training.

Keywords: Decentralized networks, Biogas, Intercrops, Crop rotation, Process network synthesis, PNS, Sustainable process index, SPI, Ecological footprint

\section{Background}

Intercrops are planted in fields between the main crop periods of e.g., wheat, corn or triticale. A typical crop rotation could be a winter type of main crops (e.g., wheat, rape etc.) followed by intercrops during the regeneration period. After the intercrop has been harvested, the main crop period starts anew. In this study, different grass species (e.g., Sudan grass, ryegrass, cocksfoot), types of grains (e.g., rye, sorghum, buckwheat, triticale, oat), legumes (e.g., pea species, vetch, horse bean, crimson

\footnotetext{
* Correspondence: nora.niemetz@tugraz.at

Institute for Process and Particle Engineering, Graz University of Technology, Inffeldgasse 21a, Graz 8010, Austria
}

clover, red clover, lucerne) and different oil seeds (e.g., sunflower, fodder radish, turnip rape) were used as examples for intercrops in corn fields [1].

The basic idea of using intercrops for energy production is twofold: using a biogenous feedstock which is strictly not in competition with the production of food, while at the same time using the nitrogen fixation potential of intercrops (via recycling biogas manure as well as by subsurface nitrogen fixation) to reduce the input of mineral fertilizer, to increase the yield per hectare, as well as to improve soil quality by humus rebuilding. Using less mineral fertilizer and achieving a higher overall yield per hectare (including the energy yield from

\section{Springer}

(c) 2012 Niemetz and Kettl; licensee Springer. This is an Open Access article distributed under the terms of the Creative Commons Attribution License (http://creativecommons.org/licenses/by/2.0), which permits unrestricted use, distribution, and reproduction in any medium, provided the original work is properly cited. 
intercrops) will result in lower overall ecological pressure of agricultural activities [2].

The case study, Bad Zell - a spa town in Upper Austria forms the background for setting up the key parameters of a supply and demand chain of substrates and energy needed for biogas technologies. An important issue in this case is the inclusion of decentralized biogas production sites, a central heat demand (in the spa town) and a feed-in to the national electricity grid. This can be achieved using different structures, featuring e.g., several separated decentralized digesters that are linked by biogas pipelines to a central combined heat and power plant (CHP), using decentralized digesters serving their own $\mathrm{CHP}$ and providing a heat transmission to the site of heat demand or any combination of these. Additionally, some digesters may be especially equipped to utilize particular substrates or substrate combinations, leading to a necessity to transport substrates from the site of their generation to suitable digesters, which may be located further away.

This case study is the first one which tries to examine all effects of intercrops on sustainable energy production. It is part of a project called 'Syn-Energy I', in which intercrops were analyzed in detail. Field tests of different kinds of intercrops from this project were used to determine the dry mass yields for this paper. The project also included an analysis of the effects of intercrops on ground water, soil, nutrient management, as well as laboratory-scale biogas digester experiments for the estimation of the biogas potential of intercrops. The results concerning intercrop yields, biogas yields from these intercrops and the ecological impact of intercrop cultivation were applied to the case study of Bad Zell; the results also were used as database for the optimization the paper deals with [3].

\section{Methods}

\section{Process network synthesis (PNS)}

The setup for this case study included different feedstock combinations as well as spatial distributions of substrate supply and heat demand for modeling and optimization. Using the Process network synthesis (PNS), an optimum structure should be the outcome of the analysis. In a first step, a technology network is generated using the PNS [4-6]. This method uses the p-graph method and works through energy and material flows [7]. The available raw materials are turned into feasible products and services, while the inputs and outputs are unequivocally given by each implemented technology. Time dependency such as resource availability as well as product or service demand (e.g., the varying heat demand for district heating over the year) is part of the optimization. This method has already been applied to various renewable resource utilization cases, including the optimal technology constellations for green biorefineries [8], the sugar industry [9] and animal residue utilization [10], to name a few.

The input necessary for this comparative modeling and optimization includes the mass and energy balances, the investment and operating costs for the considered technologies, the costs for resources and utilities, the cost of products and services, as well as the constraints regarding resource supply and product/service demand. The investment costs will be statically depreciated over a period of 15 years.

First, the so-called maximum structure is generated, linking resources with the demands (e.g., for heat) and the marketable products (e.g., electricity) via all feasible technological structures, including transport. From this starting point, the optimization is carried out resulting in an optimum structure representing the most economic constellation of technologies and logistical pathways linking the given resources with demands and market opportunities.

A discussion with regional decision makers pointed to three decentralized locations which were suitable for biogas production. In the spa town itself, it was impossible to implement a central location for digesters as it would infringe with touristic activity there. The heat needed in the town could be either generated by a centrally placed CHP with biogas transported via pipelines [11] from decentralized digesters or by decentralized CHPs used for digester heating and/or transported via transmission lines to the town. For the optimization, three digester sizes (with capacities serving 80 to 250 $\mathrm{kW}_{\mathrm{el}} \mathrm{CHP}$ ) were available for biogas production. Four combined heat and power plant capacities (from 80 to $\left.500 \mathrm{~kW}_{\mathrm{el}}\right)$ were implemented in the maximum structure. The digesters could be heated by decentralized CHPs or by a biomass furnace on site [12]. In this case, the biogas could be transported to a central CHP.

The fermentation was modeled to use different substrate feeds. The available substrates for biogas production were cattle manure, corn silage, grass silage and intercrops. Dependent on the feedstock digester sizes, the costs and digestion times differed. Seven different feedstock combinations (and hence types of digesters) were part of the maximum structure to find the most lucrative method for a substrate input strategy. These feedstock combinations are shown in Table 1.

The availability of resources was held constant within an amount of $18 \%$ grass silage, $16 \%$ corn silage and $34 \%$ intercrops (referring to fresh weight (FW)) of the available cattle manure in the region being available. Farmers in the considered region were allocated to eight provider groups regarding their spatial situation. The substrate costs were assumed to be the same within each group. The provider groups differ in the amount of available 
Table 1 Substrate feeds for fermentation

\begin{tabular}{ccccc}
\hline Feed (\%) & Cattle manure & Corn silage & Intercrops & Grass silage \\
\hline 1 & 100 & - & - & - \\
\hline 2 & 50 & 50 & - & - \\
\hline 3 & 75 & 25 & - & - \\
\hline 4 & 75 & 15 & 10 & - \\
\hline 5 & 50 & 30 & 10 & 10 \\
\hline 6 & 50 & 20 & 20 & 10 \\
\hline 7 & 75 & - & 15 & 10 \\
\hline
\end{tabular}

Seven different digesters were part of the PNS to find the most lucrative way of using the substrates. The feeds are shown in the above table.

resources as well as in the distance to each possible digester location, which directly correlates with the transport costs. Table 2 shows the total available amount of cattle manure in the region and the distances of each group to the three feasible biogas production locations.

\section{PNS: maximum structure}

In Table 3, the substrate parameters are described. The optimization was based on two different cost assumptions (maximum and minimum) concerning substrate supply.

Figure 1 shows the maximum structure for the PNS optimization, which includes all input and output materials, as well as the energy and material flows with their economic parameters such as the investment or operating costs and prices.

The transport costs included the fixed costs for loading and unloading and the variable costs which are dependent on the distance (including the unloaded runs). For solid substrates, fixed costs of $2 € / t$ fresh weight were assumed. Similarly, the conversion was carried out for the variable costs, which were assumed to be $0.49 € / \mathrm{km}$. Fixed transport costs for cattle manure with $20 € / \mathrm{t}$ dry mass as well as variable costs of $5 € / \mathrm{t}$ dry mass per kilometer were defined.
Transportation of heat and biogas could be achieved via pipeline networks. Grid operation energy demands as well as losses caused by transporting were taken into account for the heat and biogas lines. Regarding heat, it was assumed that the total produced heat amount could be used for district heating. As location 1 and 3 are in line with the spa town, one biogas pipeline could be used for both locations to transport biogas to a central CHP. Therefore, there would not be any additional costs for a biogas pipeline from location 1 to the town, as long as location 3, which is further away, supplied the center with biogas.

For silo management $150,000 €$ was allocated which can be seen as a value that is strongly dependent on the location (e.g., ground conditions, silo system used, etc.). Therefore, this number is variable and might differ from case to case.

The biomass furnaces to provide digester heating (in case biogas is transported to the central CHP units) were not implemented as a separate technology in maximum structure, but a price of $5 \mathrm{ct} / \mathrm{kWh}$ heat was assumed for heating. Electricity is fed into the national grid, thus benefiting from the feed-in tariffs according to the Austrian Eco-Electricity Act [13].

\section{Sustainable process index}

The second step included an ecological evaluation of the optimum PNS structure using the sustainable process index (SPI) [14]. Being an ecological footprint method, the SPI represents the resulting area needed to embed all necessary human activities (to supply products or services) into the ecosphere. The evaluation, itself, is based on comparing the natural flows with the human-induced flows and the natural qualities of the environmental compartments of soil, water (ground) and the atmosphere; the evaluation used solar radiation (driving all natural material cycles as well as providing a sustainable natural income to society) as a reference. The SPI results allow for analyzing ecological impacts

Table 2 Total amount of available cattle manure and provider distances to three locations in kilometers

\begin{tabular}{|c|c|c|c|c|}
\hline \multirow[t]{2}{*}{ Group } & \multirow[t]{2}{*}{ Available cattle manure (t DM) } & \multicolumn{3}{|c|}{ Distances from the provider group to the possible fermenter locations $(\mathrm{km})$} \\
\hline & & Location 1 & Location 2 & Location 3 \\
\hline 1 & 405.9 & 1.6 & 3.4 & 0 \\
\hline 2 & 99.0 & 3.3 & 4.7 & 4.0 \\
\hline 3 & 188.1 & 2.7 & 4.6 & 1.2 \\
\hline 4 & 168.3 & 1.9 & 1.4 & 3.3 \\
\hline 5 & 79.2 & 0.3 & 2.1 & 2.1 \\
\hline 6 & 99.0 & 1.5 & 2.9 & 3.0 \\
\hline 7 & 158.4 & 3.1 & 3.0 & 2.4 \\
\hline 8 & 198.0 & 3.8 & 1.9 & 3.7 \\
\hline
\end{tabular}

Table 2 includes the total amount of the available cattle manure and the distances of each group to the three locations that would be feasible for biogas production. t, tons; DM, dried mass. 
Table 3 Substrate parameters

\begin{tabular}{|c|c|c|c|c|}
\hline Parameters & Cattle manure & Corn silage & Intercrops & Grass silage \\
\hline Dry mass content (\%) & 9 & 33 & 24 & 30 \\
\hline Substrate costs ${ }^{a}$ minimum (€/t DM) & 5 & 65 & 50 & 50 \\
\hline Substrate costs ${ }^{\mathrm{a}}$ maximum (€/t DM) & 10 & 90 & 80 & 80 \\
\hline $\mathrm{CH}_{4}$ output $\left(\mathrm{m}^{3} / \mathrm{t} \mathrm{DM}\right)$ & 200 & 340 & 300 & 300 \\
\hline
\end{tabular}

In Table 3, the substrate parameters are described. The optimization is based on two different cost situations (maximum and minimum) for substrate supply.

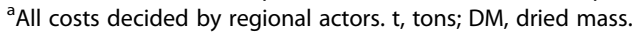

according to land use; the supply of renewable, nonrenewable and fossil resources; as well as the emissions to water, air and soil.

Footprint calculations were performed using the freeware SPIonEXCEL tool $[15,16]$. For a thorough discussion of the method, the reader is kindly referred to [15-17]. As the natural carbon cycle is included in the evaluation method as a reference flow, the SPI is well suited to compare technologies based on fossil and renewable resources. The SPI has, therefore, been applied to a number of ecological assessment tasks, especially for evaluating technologies based on renewable resources [18-20].

Using the results of the SPI evaluation, the different options could be compared regarding their environmental impact. The optimum structure obtained by the PNS is not necessarily the technology constellation with the lowest environmental impacts. By comparing the different structures and taking the two parameters (revenue of the solution and ecological footprint) into consideration, a trade-off between the economic and the ecological advantages of different structures may be possible.

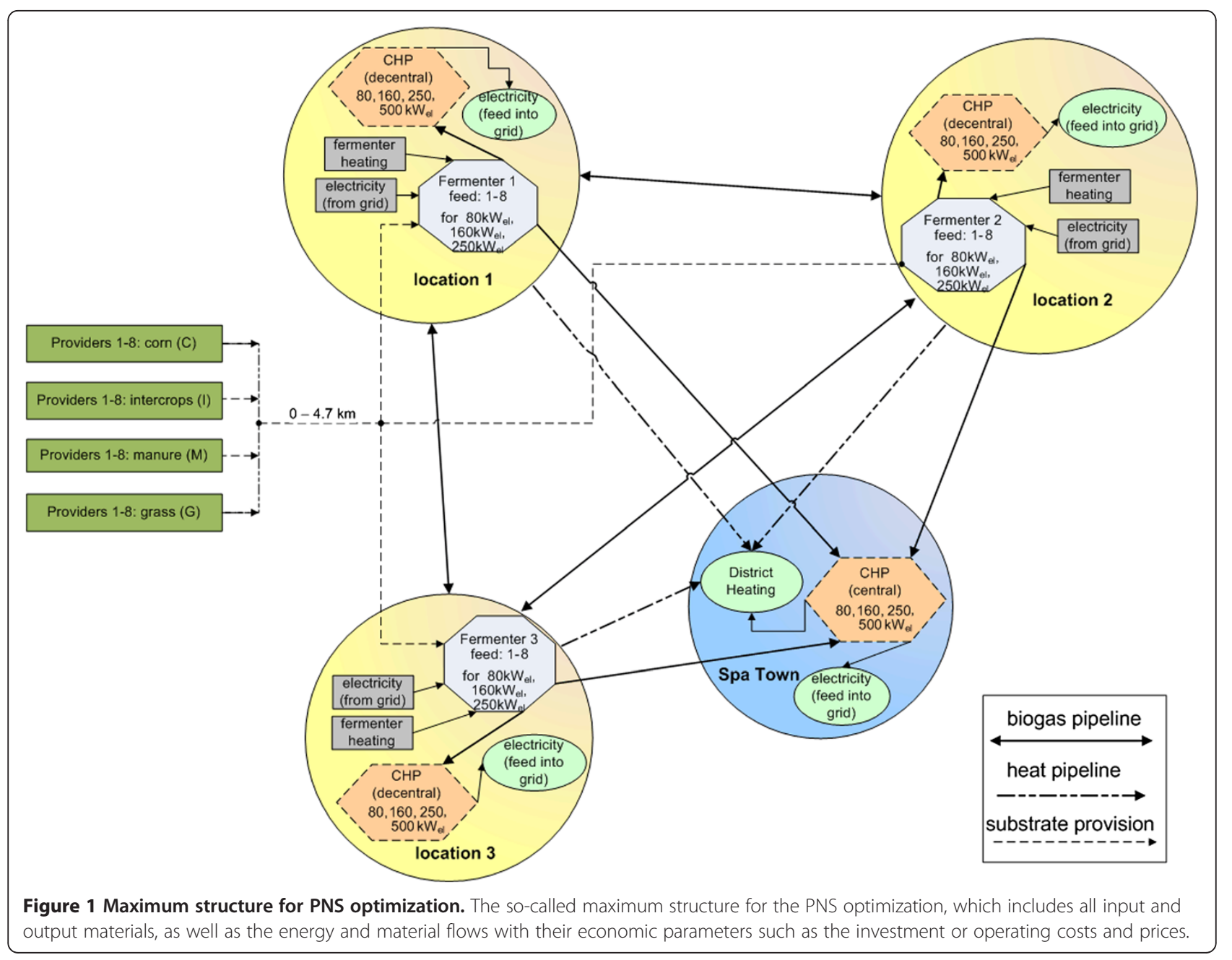




\section{Results and discussion}

\section{PNS: basic optimum structure}

The PNS optimization shows that the technology constellation providing the largest economic benefit only includes location 1 for biogas generation. On this site, biogas is produced using two different substrate feeds (6, 7 in Table 1). Therefore, two digester types are part of the optimum structure. As Table 1 demonstrates, both substrate feeds include intercrops. All provider groups can supply the digesters with at least one substrate. Figure 2 depicts the optimum structure for a situation with maximal substrate costs as listed in Table 3.

Both digesters have a size to supply a $250 \mathrm{~kW}_{\mathrm{el}} \mathrm{CHP}$. The one with the higher amount of intercrops in the feed (f6) runs at full load, while the other (f7) runs at $96 \%$ of capacity. Altogether, around 1,116,300 $\mathrm{m}^{3}$ of methane $\left(\mathrm{CH}_{4}\right)$ can be produced. Around one-third of the biogas generated by digester $\mathrm{f} 6$ is used in a decentralized $160 \mathrm{~kW}_{\mathrm{el}} \mathrm{CHP}$ (51\% capacity) on site, whereas the digester $\mathrm{f} 7$ fully supplies biogas via pipelines to a central CHP with a capacity of a $250 \mathrm{~kW}_{\mathrm{el}}$. The rest of the biogas produced by digester f6 is sent via pipelines to the center and runs a CHP of $160 \mathrm{~kW}_{\mathrm{el}}$ in full load mode. In total, around 4,130 MWh heat per year can cover the district heat demand at a price of $2.25 \mathrm{ct} / \mathrm{kWh}$. Both CHP units feed electricity into the national grid (approximately 3,830 MWh/year) at feed-in tariffs of 20.5 ct/kWh (see also Table 4).

Using this technology constellation and a 15 -year depreciation period, a total annual profit of nearly 229,000 $€$ can be achieved (interest rates are not included). The total input costs including electricity consumed from the grid add up to $236,000 € /$ year with an additional 68,170 $€ /$ year for transportation. The investment costs for this technology constellation are $2,805,800 €$, including the district heating and biogas network as well as the costs for the digesters, the CHPs and the other infrastructures needed.

The optimization using a minimum cost situation (see Table 3) results in the same optimum network structure as has already been shown in Figure 2. The costs for the substrates are lower (around 163,920 €/year). The profit increases to $301,000 € /$ year (without taking interest rates into account). Table 4 gives an overview of the monetary input and output parameters for both cost situations.

\section{Scenario generation}

Two scenarios were developed both for minimum as well as for maximum substrate cost situations: scenario 1 with a reduced maximum structure does not include corn availability (only feed combinations 1 and 7 are feasible in this scenario); scenario 2 used cattle manure as a substrate only. These scenarios rendered the following results:

\section{Scenario 1}

Biogas is produced only at location 1 with a total amount of 751,000 $\mathrm{m}^{3} \mathrm{CH}_{4}$ per year, using two digesters (both f7). A local $80 \mathrm{~kW}_{\mathrm{el}}$ CHP covers the heat demand of the biogas digesters. In the town center, a $250 \mathrm{~kW}_{\mathrm{el}}$ $\mathrm{CHP}$ runs with biogas produced at site 1 . Figure 3 shows the optimum technology constellation for scenario 1 .

The optimum structure of a scenario with a maximum substrate cost constellation provides a yearly profit of $119,460 €$ (again excluding the interest rates). If the substrate costs are set to minimum, the structure does not change, but the annual profit increases due to the lower material costs up to about $166,000 € /$ year. Table 5 compares the minimum and maximum substrate cost constellation for scenario 1 .

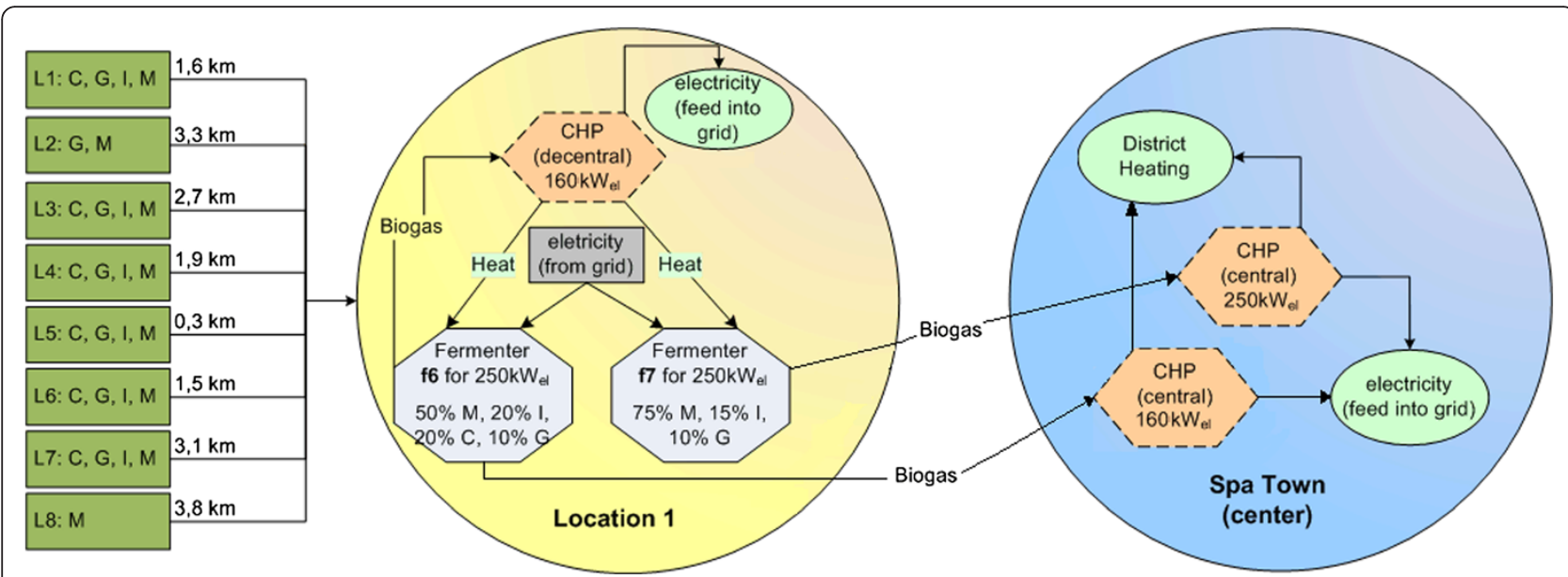

Figure 2 Basic optimum structure of a technology constellation generated using the PNS. This depicts the basic optimum structure for a situation with maximal substrate costs as listed in Table 1. 
Table 4 Comparison of monetary parameters for minimum and maximum substrate costs

\begin{tabular}{|c|c|c|c|}
\hline Depreciation period: 15 years & Minimum & Maximum & Capacity (\%) \\
\hline \multicolumn{4}{|l|}{ Total investment costs $(1,000 €)$} \\
\hline Digester f6 $250 \mathrm{~kW}$ el & 850.9 & 850.9 & 100 \\
\hline Digester f7 $250 \mathrm{~kW}$ el & $1,075.6$ & $1,075.6$ & 96 \\
\hline CHP 160 kWel location 1 & 200 & 200 & 51 \\
\hline CHP $160 \mathrm{~kW}_{\mathrm{el}}$ central & 200 & 200 & 100 \\
\hline CHP $250 \mathrm{~kW}_{\mathrm{el}}$ central & 250 & 250 & 100 \\
\hline Transformer & 35 & 35 & - \\
\hline Silo management & 150 & 150 & - \\
\hline Biogas pipelines & 44.3 & 44.3 & - \\
\hline Total investment costs & $2,805.8$ & $2,805.8$ & - \\
\hline Yearly depreciation (1,000 €/year) & 187.1 & 187.1 & - \\
\hline \multicolumn{4}{|l|}{ Yearly operating costs (1000 €/year) } \\
\hline Material costs & 129.5 & 201.6 & - \\
\hline Transport costs & 68.2 & 68.2 & - \\
\hline Digester f6 $250 \mathrm{~kW}$ el & 37.8 & 37.8 & 100 \\
\hline Digester f7 $250 \mathrm{~kW}_{\mathrm{el}}$ & 37.8 & 37.8 & 96 \\
\hline CHP 160 kWel location 1 & 23.3 & 23.3 & 51 \\
\hline CHP $160 \mathrm{~kW}_{\mathrm{el}}$ central & 23.3 & 23.3 & 100 \\
\hline CHP $250 \mathrm{~kW}_{\mathrm{el}}$ central & 29.2 & 29.2 & 100 \\
\hline Silo management & 5.9 & 5.9 & - \\
\hline Electricity from national grid & 34.4 & 34.4 & - \\
\hline Total operating costs (1,000 €/year) & 389.4 & 461.5 & - \\
\hline \multicolumn{4}{|l|}{ Yearly profit (1,000 €/year) } \\
\hline District heat $22.5 € \times 4,134 \mathrm{MWh}$ & 93.0 & 93.0 & - \\
\hline Electricity feed in $205 € \times 3,827 \mathrm{MWh}$ & 784.4 & 784.4 & - \\
\hline Total profit $(1,000 € / \text { year })^{a}$ without depreciation and operating costs & 877.4 & 877.4 & - \\
\hline Total profit $(1,000 € / \text { year })^{a}$ & 300.9 & 228.9 & \\
\hline
\end{tabular}

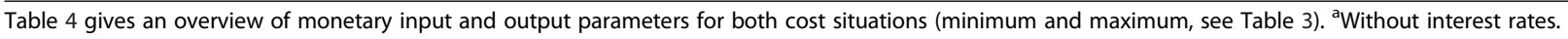

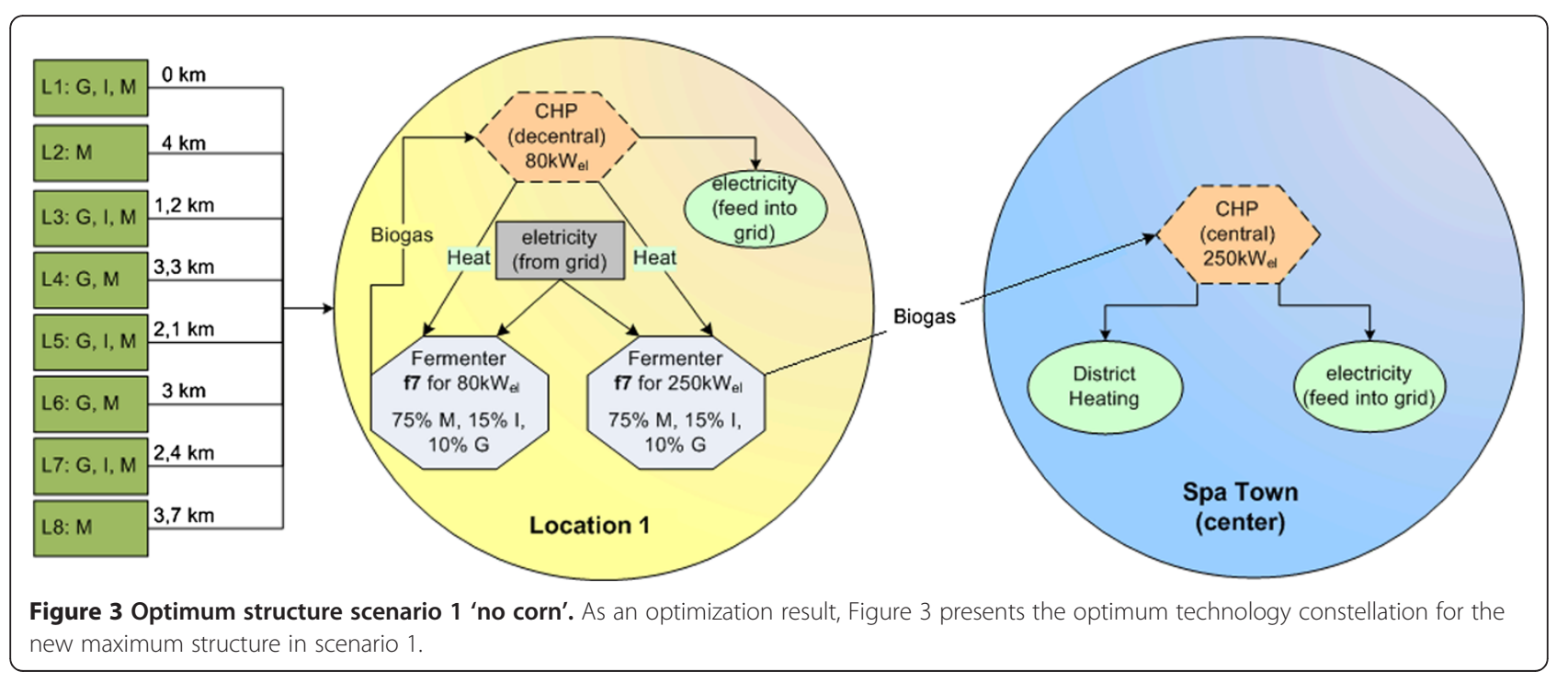


Table 5 Comparison of the results for minimum and maximum substrate costs for scenario 1

\begin{tabular}{|c|c|c|c|}
\hline Depreciation period: 15 years & Minimum & Maximum & Capacity (\%) \\
\hline \multicolumn{4}{|l|}{ Total investment costs $(1,000 €)$} \\
\hline Digester f7 80 kWel & 474.7 & 474.7 & 100 \\
\hline Digester f7 250 kWel & $1,075.6$ & 1075.6 & 100 \\
\hline CHP 80 kWel location 1 & 110 & 110 & 100 \\
\hline CHP 250 kWel central & 250 & 250 & 100 \\
\hline Transformer & 35 & 35 & - \\
\hline Silo management & 150 & 150 & - \\
\hline Biogas pipelines & 44.3 & 44.3 & - \\
\hline Total investment costs & $2,139.6$ & 2139.6 & - \\
\hline Yearly depreciation (1,000 €/year) & 142.6 & 142.6 & - \\
\hline \multicolumn{4}{|l|}{ Yearly operating costs (1,000 €/year) } \\
\hline Material costs & 73.0 & 119.6 & - \\
\hline Transport costs & 56.6 & 56.6 & - \\
\hline Digester f7 $80 \mathrm{~kW}$ el & 27.1 & 27.1 & 100 \\
\hline Digester f7 250 kWel & 37.8 & 37.8 & 100 \\
\hline CHP 80 kWel location 1 & 18.9 & 18.9 & 100 \\
\hline CHP 250 kWel central & 29.2 & 29.2 & 100 \\
\hline Silo management & 5.9 & 5.9 & - \\
\hline Electricity from national grid & 23.2 & 23.2 & - \\
\hline Total operating costs (1,000 €/year) & 271.7 & 318.3 & - \\
\hline \multicolumn{4}{|l|}{ Yearly profit (1,000 €/year) } \\
\hline District heat $22.5 € \times 2,340 \mathrm{MWh}$ & 52.6 & 52.6 & - \\
\hline Electricity feed in $205 € \times 2,574 \mathrm{MWh}$ & 527.7 & 527.7 & - \\
\hline Total profit $(1,000 € / \text { year) })^{a}$ without depreciation and operating costs & 580.3 & 580.3 & - \\
\hline Total profit $(1,000 € / \text { year })^{a}$ & 166.0 & 119.5 & \\
\hline
\end{tabular}

\section{Scenario 2}

The input materials of the maximum structure (Figure 1) are dramatically changed. In scenario 2 , only cattle manure is available as a substrate for biogas fermentation. With that, only feedstock 1 can be used to produce biogas and no silo management is needed.

The optimization shows that just location 1 is feasible for biogas fermentation. Biogas can be produced in a digester of a capacity to supply a $160 \mathrm{~kW}$ el $\mathrm{CHP}(78.7 \%$ capacity). The produced biogas with an amount of $286,420 \mathrm{~m}^{3} \mathrm{CH}_{4}$ is used in a decentralized $160 \mathrm{~kW}$ el $\mathrm{CHP}$ on site. The heat demand for the digester at location 3 is covered by this CHP. The rest of the heat (about $790 \mathrm{MWh} /$ year) is sent via heat pipelines to the center where it is sold for a price of $22.5 € / \mathrm{MWh}$.

In this scenario with maximum substrate costs of $9 € / t$ dry mass, no profit can be gained. The optimum structure for scenario 2 results in a yearly loss of about 6,100 $€$ (not including interest rates). If the substrate costs are set to minimum, the structure does not change but a little profit of about $900 €$ /year can be achieved.

\section{Ecological evaluation}

Any meaningful ecological evaluation requires a precise definition of the system boundaries. In this study, the evaluation of the field crops started at the point of crop sowing. Energy (especially fuel), fertilizer and pesticide input for all steps of cultivation (such as sowing, plowing and fertilizing), as well as the infrastructure of the technical equipment are included. For cattle manure, the system boundary includes the cattle as a manure producer, taking feed (wheat and grass) into account. Cattle are regarded as means to produce meat, milk and manure. An ecological pressure is assigned to these products by price allocation. A low footprint for manure results as the manure price is rather low (approximately $1 € / \mathrm{t} \mathrm{FW)}$ compared to the main product of milk (about $288 € / \mathrm{t}$ FW). The intercrop evaluation is based on precise data from actual cultivation experiments during the project. A major part of the ecological footprint is caused by transport. In the structures described before the transport situation, the location for biogas plants is also location 1. But as presented in Table 2, the provider 
distances differ depending on the location, whereas the substrate amounts differ depending on the scenarios, leading to considerably different ecological pressures due to transport. Table 6 provides an overview of the main parameters for SPI evaluation [21].

Table 6 shows that the structure with the largest economic benefit entails the highest ecological pressure. This is a result of the high amount of corn (with its high SPI value of $86,216 \mathrm{~m}^{2} / \mathrm{t} \mathrm{DM}$ ) used in this structure. The SPI values are dominated by machinery use (causing fossil fuel consumption and $\mathrm{CO}_{2}$ emissions) and fertilizer use for growing corn. In scenario 1, the corn input is put to zero. This change decreases the SPI value considerably. Scenario 2 has the lowest SPI value because it uses only manure of a small footprint as the substrate $\left(1,887 \mathrm{~m}^{2} / \mathrm{t} \mathrm{DM}\right)$. This scenario, however, achieves little or no economic profit.

The amount of product differs widely between the scenarios with the 3,827 $\mathrm{MWh} /$ year electricity in the basic optimum structure: in scenario 1 , the produced electricity decreases by one-third. In scenario 2, only 978 MWh/year can be fed into the grid. Accordingly, the material input varies and with that the SPI values. Figure 4 indicates the SPI per megawatt hour (MWh) electricity produced dividing each bar into the seven SPI sub-categories. The figure shows that the most important impacts resulting from the input of fossil resources were mainly caused by the fuel for the machinery, the fertilizers and the electricity use. The emissions to air and water are mainly due to the production of electricity based on fossil and nuclear materials.
Compared to the basic optimum structure (Figure 2), the two scenarios have a lower ecological footprint per MWh of electricity. But a disadvantage of scenario 1 and 2 is that more digesters or higher capacities are required to produce the same biogas amount compared to the basic optimum structure where corn silage can be used as the substrate. This does not really affect the ecological footprint, but it is also a reason for the decreased revenue of scenario 1 and 2 as the investment costs change.

\section{Social aspects}

In general, the first reactions from actors regarding the production of intercrops show that the psychological barriers are of high importance: farmers expect low yields (as are common for intercrops) and, therefore, tend to disregard biogas production from intercrops. Because farmers have to put in additional effort and must adhere to strict timing, barriers to using intercrops are raised. Another aspect is that in order to fully benefit from intercrop cultivation via the production of biogas, large investments as well as close economic and operational co-operation between the farmers and other local actors is required. It seems like all these arguments and facts are speaking against implementing complex solutions. Therefore, it is even more important to raise awareness and to offer external incentives (e.g., funding) to convince the farmers of the fact that intercrops may contribute to a higher overall added value as the optimum structure clearly shows.

Table 6 Main parameters for SPI evaluation [21]

\begin{tabular}{|c|c|c|c|}
\hline Yearly & Optimum & Scenario 1 & Scenario 2 \\
\hline Corn silage (t DM/year) & 537 & 0 & 0 \\
\hline Corn silage SPI (m²/t DM) & 86,216 & 86,216 & 86,216 \\
\hline Intercrops (t DM/year) & 960 & 1,351 & 0 \\
\hline Intercrops SPI (m²/t DM) & 9,250 & 9,250 & 9,250 \\
\hline Grass silage (t DM/year) & 711 & 375 & 0 \\
\hline Grass silage $\mathrm{SPI}\left(\mathrm{m}^{2} / \mathrm{t} \mathrm{DM}\right)$ & 7,640 & 7,640 & 7,640 \\
\hline Cattle manure (t DM/year) & 1,393 & 895 & 931 \\
\hline Cattle manure SPI (m²/t DM) & 1,887 & 1,887 & 931 \\
\hline Electricity from grid (MWh/year) & 230 & 154 & 37 \\
\hline \multicolumn{4}{|l|}{ Produced heat } \\
\hline Total (MWh/year) & 5,038 & 3,159 & 1,412 \\
\hline Out of that for district heating (MWh/year) & 4,134 & 2,340 & 790 \\
\hline Electricity feed (MWh/year) & 3,827 & 2,574 & 978 \\
\hline CHP capacity $\left(\mathrm{kW}_{\mathrm{el}}\right)$ & $160 ; 160 ; 250$ & $80 ; 250$ & 160 \\
\hline SPI electricity (m²/MWh) & 53,437 & 19,305 & 18,327 \\
\hline SPI heat (m²/MWh) & 5,865 & 2,119 & 2,012 \\
\hline SPI total $\left(\mathrm{km}^{2}\right)$ & 204.5 & 49.7 & 17.9 \\
\hline
\end{tabular}




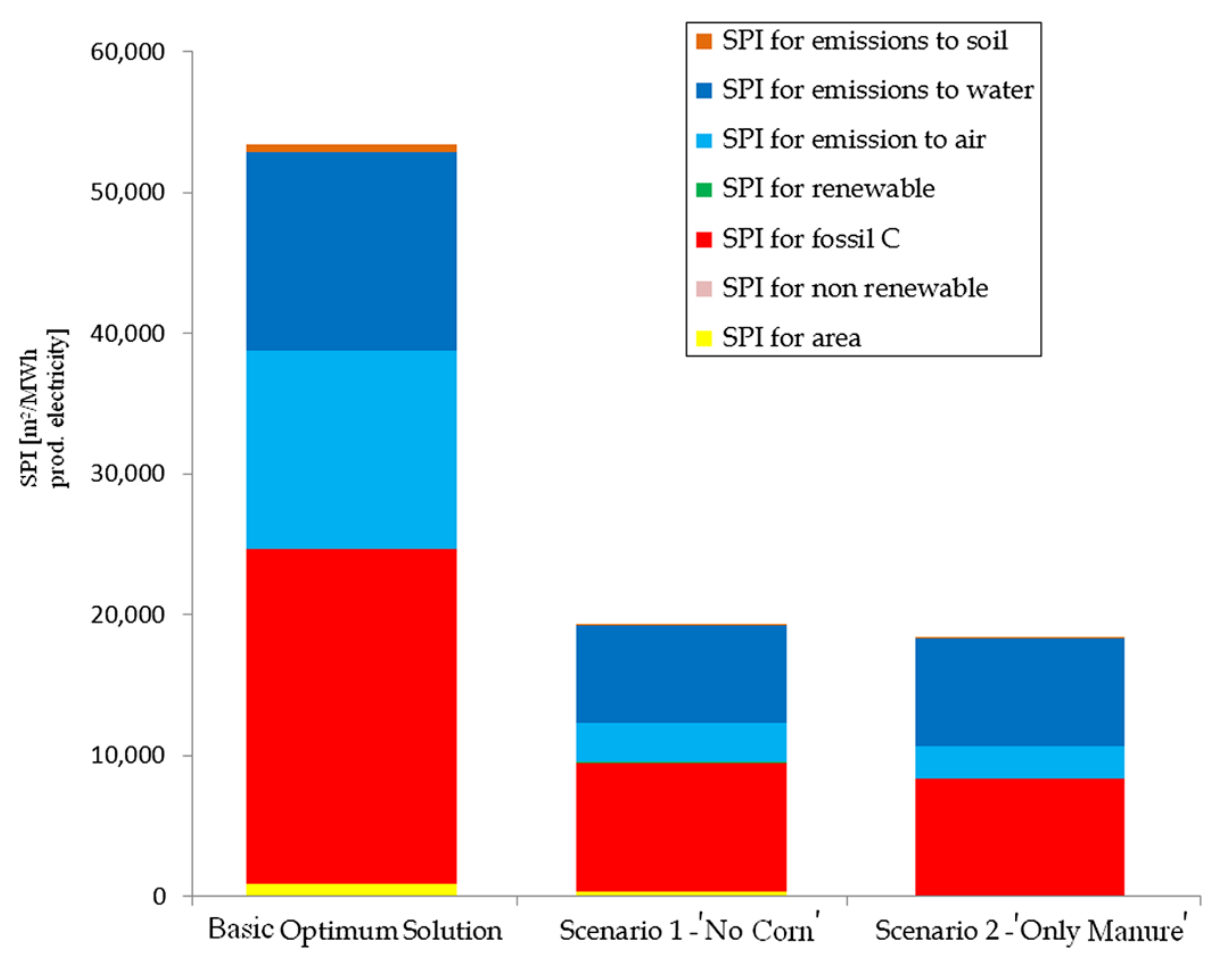

Figure 4 SPI values per MWh electricity produced. The presented table divides each bar into the seven SPI categories. The figure reveals that the major impact resulted from the demand of fossil resources mainly caused by machinery and electricity use.

\section{Conclusions}

Ecological, economic and social sustainability aspects should be considered at the same time when new concepts are introduced to provide energy from bioresources. Using the PNS to generate optimal constellations for linking resources with demands and the markets via integrated technologies, it has proven to be helpful to generate scenarios and evaluate them ecologically using an encompassing methodology, such as the SPI. The latter provided a clear picture regarding the interplay between ecological and economic factors. In this study, the applied approach highlighted the trade-off between ecology and the economy, best represented in Figure 4 where scenario 1 has been identified as the solution which optimizes economic as well as ecological benefits.

The social aspects will, however, be decisive for implementing innovative energy systems based on renewable resources. It was demonstrated that the production of intercrops for producing biogas so far has not been regarded as a viable option by the farmers due to a variety of barriers. Additional work and a strict time frame to cultivate their fields are the main counter-arguments in the discussion about intercrops, coupled with the necessity to a close cooperation and mutual dependency between farmers as well as between agriculture and other social actors on the local level. A rise in awareness is needed to emphasize that planting intercrops holds many advantages. Intercrops reduce the ecological footprint decisively. In times of green taxes, a reduction of $\mathrm{CO}_{2}$ emissions can also decrease production costs. More biogas output per hectare raises income while a reduced need for mineral fertilizer reduces costs. This issue should be taken up by agricultural training courses, where the advantages could be demonstrated on the example of the best practice demonstrative farms.

A crucial logistical aspect would be an intelligent digester set-up and an innovative approach regarding biogas and heat logistics. All this, however, calls for a high level of organization, possibly in the form of a farmer association running the network constellation described before, to lower the investment risk and ensure a continuous operation and stable substrate availability. On the other hand, such an association has the potential to strengthen the community and the social cohesion in the region. On closer examination, it reveals that intercrops can play an important role in a sustainable agriculture of the future when developing and running a socially and ecologically acceptable network constellation still being lucrative for the operators and the region.

\section{Abbreviations}

$\mathrm{CH}_{4}$ : methane; CHP: combined heat and power plant; ct: cent; DM: dried mass; FW: fresh weight; kWel: kilowatt electric; kWh: kilowatt hour; MWh: megawatt hour; PNS: process network synthesis; SPI: sustainable process index. 


\section{Competing interests}

The authors declare that they have no competing interests.

\section{Authors' contributions}

NN collected the data, carried out the PNS evaluation, as well as its interpretation, and drafted the manuscript. KHK provided the SPI evaluation data and interpretation. Both authors read and approved the final manuscript.

\section{Author's information}

NN, born in 1982 in Vienna, Austria, holds a diploma in environmenta system sciences. She is currently working in the field of process evaluation at the Institute for Process and Particle Engineering, Graz University of Technology (GUT). Her main research topics are the implementation of sustainable system structures/networks at a regional level and sustainable resource management. GUT is the second technical university in Austria with 104 institutes in six faculties and around 12,000 students in bachelor, master and doctoral programs.

\section{Acknowledgments}

The authors would like to thank their fellow researchers Dr. Manfred Szerencsits and Ing. Ferdinand Köberl for data provision and assistance. They both belong to Ökocluster, part of the project team in Syn-Energy I, 'Klima und Wasserschutz durch synergetische Biomassenutzung - Biogas aus Zwischenfrüchten, Rest- und Abfallstoffen ohne Verschärfung der Flächenkonkurrenz'. The authors are also grateful to all other fellow researchers and project partners who made this study possible. The research presented here was carried out under the project 'Syn-Energy l' funded by the Austrian Climate and Energy Fund and carried out within the program 'NEUE ENERGIEN 2020' (grant number 819034).

Received: 1 September 2011 Accepted: 24 August 2012

Published: 4 September 2012

\section{References}

1. Szerencsits M Begrünungsversuche in Österreich und Deutschland. Paper presented at the 2nd Feldtag 'Bodenschutz bei Anbau und Einbringung von Begrünungen', Stockerau, 5 November 2010

2. Szerencsits M, Kettl KH, Allesch A (2011) Synergetischer Klimaschutz mit Biogas aus Zwischenfrüchten - Bereitstellung erneuerbarer Energie bei gleichzeitiger Verminderung negativer Klima und Umweltwirkungen der Landwirtschaft. Paper presented at the 12th AustroClim (Austrian Climate Day). Wilhelm Exnerhaus University of Natural Resources and Applied Life Sciences, Vienna, 21-22 September 2011

3. Birnstingl B, Riebenbauer L, Szerencsits M, Allesch A, Kuderna M, Legath S, Kettl KH, Niemetz N, Narodoslawsky M, Sandor NK (2011) Syn-Energy - Klima und Wasserschutz durch synergetische Biomassenutzung - Biogas aus Zwischenfrüchten, Rest, und Abfallstoffen ohne Verschärfung der Flächenkonkurrenz, Endreport. Project funded by the Austrian Climate and Energy Fund and carried out within the programme 'NEUE ENERGIEN 2020 (grant number 819034, Neue Energien 2020 1. Ausschreibung), Vienna, in press

4. Friedler F, Varga JB, Fan LT (1995) Decision-mapping: a tool for consistent and complete decisions in process synthesis. Chemical Engineering Science 50:1755-1768

5. Halasz L, Eder M, Sandor NK, Niemetz N, Kettl KH, Narodoslawsky M (6-9 June 2010) Energy optimised regions - a process synthesis problem? In: $20^{\text {th }}$ European symposium on computer aided process engineering conference on process integration, modelling and optimisation for energy saving and pollution reduction, S, Ischia, pp 1895-1900

6. Niederl-Schmidinger A (2005) Process synthesis and life cycle assessment tools for sustainable technology development. Graz University of Technology, Dissertation

7. Friedler F, Tarjan K, Huang YW, Fan LT (1992) Graph-theoretic approach to process synthesis: axioms and theorems. Chemical Engineering Science 47:1973-1988

8. Narodoslawsky M, Niederl A, Halasz L (2008) Utilising renewable resources economically: new challenges and chances for process development. Journal of Cleaner Production 16(2):164-170
9. Halasz L, Gwehenberger G, Narodoslawsky M (2007) Process synthesis for the sugar sector - computer based insights in industrial development. Computer Aided Chemical Engineering 24:431-436

10. Niederl A, Halasz L, Nagy A (2005) Sensitivity analysis of network synthesis models - the case of animal residue utilization. Chemical Engineering Transactions 7(2):489-494

11. Szerencsits M (2010) Biogas und Gülleleitungen - Wege zur optimalen Wärmenutzung und Gülleerfassung. Paper presented at Biogas Expo and Congress Fair, Offenburg, 20-21 October 2010

12. Wagner R (2008) Ökonomischer und energetischer Vergleich von Biogasleitungen mit Warmwasserleitungen zur besseren Wärmeverwertung, Available via C.A.R.M.E.N. http://www.carmen-ev.de/dt/hintergrund/biogas/ vergl_biogasleitungen.pdf. Accessed August 2011

13. RIS (2011) Ökostromgesetz, Available via RIS (Rechts informations system Bundeskanzleramt). http://www.ris.bka.gv.at/GeltendeFassung.wxe?Abfrage =Bundesnormen\&Gesetzesnummer=20002168. Accessed August 2011

14. Narodoslawsky M, Krotscheck C (1995) The sustainable process index (SPI) - evaluating processes according to environmental compatibility. Journal of Hazardous Materials 41:383-397

15. SPI. http://spionexcel.tugraz.at. Accessed August 2012

16. Sandholzer D, Niederl A, Narodoslawsky M (2005) SPlonExcel - fast and easy calculation of the sustainable process index via computer. Chemical Engineering Transactions 7(2):443-446

17. Narodoslawsky M, Niederl A (2005) In: Dewulf J, van Langhove H (eds) Sustainable process index, renewable-based technology: sustainability assessment, 10th edn. NY, Wiley

18. Niederl A, Narodoslawsky M (2004) Ecological evaluation of processes based on by-products or waste from agriculture - life cycle assessment of biodiesel from tallow and used vegetable oil. In: Feedstocks for the future, 18th edn. ACS symposium Series 921, Anaheim, USA

19. Narodoslawsky M, Gwehenberger G (2007) The ecological impact of the sugar sector- aspects of the change of a key industrial sector in Europe. Computer Aided Chemical Engineering 24:1029-1034

20. Narodoslawsky M, Stoeglehner G How sustainable are biofuels? Answers and further questions arising from an ecological footprint perspective. Bioresource Technol 100(16):S.3825-S.3830

21. Ecoinvent Database (2012) Ecoinvent Center, http://www.ecoinvent.ch. Accessed January 2012

doi:10.1186/2192-0567-2-18

Cite this article as: Niemetz and Kettl: Ecological and economic evaluation of biogas from intercrops. Energy, Sustainability and Society 2012 2:18

\section{Submit your manuscript to a SpringerOpen ${ }^{\odot}$ journal and benefit from:}

- Convenient online submission

- Rigorous peer review

- Immediate publication on acceptance

- Open access: articles freely available online

- High visibility within the field

- Retaining the copyright to your article

Submit your next manuscript at $>$ springeropen.com 